\title{
Analysis of the gene expression profile in response to human epididymis protein 4 in epithelial ovarian cancer cells
}

\author{
LIANCHENG ZHU $^{1 *}$, QIAN GUO $^{1 *}$, SHAN JIN $^{1}$, HUILIN FENG $^{1}$, HUIYU ZHUANG $^{1,2}$,

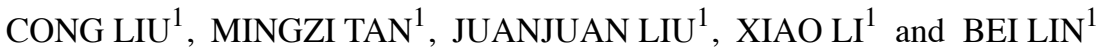 \\ ${ }^{1}$ Department of Obstetrics and Gynecology, Shengjing Hospital of China Medical University, Shenyang, Liaoning 110004; \\ ${ }^{2}$ Department of Obstetrics and Gynecology, Beijing Chaoyang Hospital Affiliated to \\ Capital Medical University, Beijing 100043, P.R. China
}

Received February 21, 2016; Accepted March 30, 2016

DOI: $10.3892 / o r .2016 .4926$

\begin{abstract}
Currently, there are emerging multiple studies on human epididymis protein 4 (HE4) in ovarian cancer. HE4 possesses higher sensitivity and specificity than CA125 in the confirmative early diagnosis for ovarian cancer. Although much attention has been given to explore its clinical application, research of the basic mechanisms of HE4 in ovarian cancer are still unclear. In the present study, we provide fundamental data to identify full-scale differentially expressed genes (DEGs) in response to HE4 by use of human whole-genome microarrays in human epithelial ovarian cancer cell line ES-2 following overexpression and silencing of HE4. We found that a total of 717 genes were upregulated and 898 genes were downregulated in the HE4-overexpressing cells vs. the HE4-Mock cells, and 166 genes were upregulated and 285 were downregulated in the HE4-silenced cells vs. the HE4-Mock cells. An overlap of 16 genes consistently upregulated and 8 genes downregulated in response to HE4 were noted. These DEGs were involved in MAPK, steroid biosynthesis, cell cycle, the p53 hypoxia pathway, and focal adhesion pathways. Interaction network analysis predicted that the genes participated in the regulatory connection. Highly differential expression of the FOXA2, SERPIND1, BDKRD1 and IL1A genes was verified by quantitative real-time PCR in 4 cell line samples. Finally, SERPIND1 (HCII) was validated at the protein level by immunohistochemistry in 107 paraffinembedded ovarian tissues. We found that SERPIND1 may act as a potential oncogene in the development of ovarian cancer. The present study displayed the most fundamental and fullscale data to show DEGs in response to HE4. These identified
\end{abstract}

Correspondence to: Dr Bei Lin, Department of Obstetrics and Gynecology, Shengjing Hospital of China Medical University, 36 Sanhao Street, Shenyang, Liaoning 110004, P.R. China

E-mail: linbei88@hotmail.com

*Contributed equally

Key words: gene expression profile, HE4, epithelial ovarian carcinoma, SERPIND1, HCII genes may provide a theoretical basis for investigations of the underlying molecular mechanism of HE4 in ovarian cancer.

\section{Introduction}

Ovarian cancer is the most lethal gynecological malignancy and accounts for $25-30 \%$ of all malignant tumors in the female reproductive tract. An estimated 22,280 new cases of ovarian cancer and 14,240 related deaths were reported in 2016 in the US (1). Due to its innocuous symptoms, most ovarian cancer patients are diagnosed at the late stage. Despite the development of new antitumor drugs and the improvement of surgical treatment, the majority of patients with advanced disease (stages III-IV) eventually relapse and the 5-year survival rate of late stage patients is only $30 \%$ (2). Therefore, early diagnosis of ovarian cancer is crucial to reduce mortality and improve the prognosis for eventual survival. Human epididymis protein 4 (HE4), also known as whey-acidic-protein (WAP) four-disulfide core domain protein 2 (WFDC2), was first found overexpressed in ovarian cancer tissue in 1999 (3). Although it was originally recognized as a small secreted protein that plays a role in sperm maturation in males (4), numerous studies have found that HE4 is a valuable serum biomarker possessing higher sensitivity and specificity than CA125 in the confirmative early diagnosis for epithelial ovarian cancer (EOC) $(5,6)$, and the combined use of HE4 with pelvic ultrasound achieved the best sensitivity for detecting ovarian cancers among the different algorithms tested (7). It seems to be an independent predictive factor for ideal tumor cytoreductive surgery and maintains its prognostic role even after recurrence (8). Moreover, recent investigations have shown that serum HE4 could predict chemotherapy response during first-line chemotherapy (9), and high HE4 levels are correlated with chemoresistance and decreased survival rates in EOC patients $(10,11)$. HE4 shows its potential application as a biomarker for early detection and discrimination of endometrial $(12,13)$ and non-small cell lung cancer $(14)$, and pancreatic adenocarcinoma (15). A high serum HE4 level may be a useful biomarker for the poor prognosis in non-small cell lung cancer patients $(16,17)$.

Over the past decade, much attention has been given to explore the clinical application of HE4 as a biomarker. In 
Table I. Cell line sample description and RNA qualification.

\begin{tabular}{llcccc}
\hline Sample ID & Label & OD260/280 & OD260/230 & RIN & Results \\
\hline HE4-H & O & 2.02 & 2.21 & 9.30 & Pass \\
HE4-H-vector & OV & 2.02 & 2.35 & 8.60 & Pass \\
HE4-L & S & 2.02 & 2.24 & 10.0 & Pass \\
HE4-L-vector & SV & 2.03 & 2.09 & 9.00 & Pass \\
\hline
\end{tabular}

RIN, RNA Integrity number; HE4, human epididymis protein 4.

recent years, several studies have reported that HE4 acts as an oncogene implicated in various cancer behaviors, such as cell adhesion (18), proliferation, migration, metastasis (19-21) and chemoresistance $(19,22)$. The molecular mechanisms may be attributed to the activation of epidermal growth factor (EGF) (18), vascular endothelial growth factor (VEGF) (19), HIF1a (19) or the interaction with Annexin A2 (23), and Lewis y glycosylation (24). Nevertheless, investigation of the role of HE4 in the malignant biological behaviors of ovarian cancer is limited.

Therefore, in the present study, we sought to investigate alteration of the gene expression profile in response to HE4 in ovarian cancer cells. The results obtained from this research may lead to a better understanding of the molecular mechanisms associated with HE4 in ovarian cancer and to facilitate the early diagnosis and therapeutic treatment of ovarian cancer.

\section{Materials and methods}

Cell culture, construction of expression vectors and HE4 gene transfection. Human EOC ES-2 cells were purchased from the American Type Culture Collection (ATCC; Manassas, VA, USA) and maintained in RPMI-1640 medium with $10 \%$ fetal bovine serum (FBS) and $1 \%$ penicillin/streptomycin, at $37^{\circ} \mathrm{C}$ in a humidified atmosphere with $5 \% \mathrm{CO}_{2}$. An HE4 expression construct was generated by subcloning PCR-amplified full-length human HE4 cDNA into the pEGFP-N1 or pCMV6 plasmid. The following primers were used: P1, 5'-TCC GCT CGA GAT GCC TGC TTG TCG CCT AG-3' and P2, 5'-ATG GGG TAC CGT GAA ATT GGG AGT GAC ACA GG-3'. Two shRNA expression vectors for human HE4 were constructed using the vector pSilencer. The mRNA target sequences chosen for designing HE4-shRNA were: GTC CTG TGT CAC TCC CAA T for HE4-shRNA1 and GAT GAA ATG CTG CCG CAA T for HE4-shRNA2. Transfection was carried out using liposomes with a vector transfection kit according to the instructions. Regarding the stable cell lines, HE4-overexpressing (HE4-H) (O), HE4-shRNA low-expressing (HE4-L) (S) and their respective empty-plasmid transfected cell lines [HE4-H-Mock (OV) and HE4-L-Mock (SV)] were selected for 14 days with G418 (800 $\mu \mathrm{g} / \mathrm{ml})$ (Invitrogen, Carlsbad, CA, USA). All cell lines were labeled and are listed in Table I.

Transfection identification by quantitative real-time PCR and western blotting

Quantitative real-time polymerase chain reaction (RT-PCR). Total RNA was extracted with TRIzol reagent and reverse-tran- scribed to cDNA using SuperScript III (both from Invitrogen). Quantitative real-time PCR was performed on Roche LightCycler 480 (Roche Diagnostics, Mannheim, Germany) sequence detection system. The primers for HE4 were: 5'-AGT GTC CTG GCC AGA TGA AAT G-3' for forward and 5'-CAG GTG GGC TGG AAC CAG AT-3' for reverse. GAPDH was used to normalize the quantity of complementary DNA. PCR reactions of each sample were carried out in triplicate. The cycle steps were $95^{\circ} \mathrm{C}$ for $5 \mathrm{~min}, 40$ cycles of $95^{\circ} \mathrm{C}$ for $15 \mathrm{sec}$, $60^{\circ} \mathrm{C}$ for $1 \mathrm{~min}$ and $72^{\circ} \mathrm{C}$ for $20 \mathrm{sec}$.

Western blotting. Western blotting was performed as previously described (23). The HE4 antibody (rabbit polyclonal; 1:40; Abcam, Cambridge, MA, USA) was used and the negative control contained only HE4 antibody without protein. The protein bands were visualized by Image J $1.31 \mathrm{v}$ and normalized relative to the GAPDH protein expression level.

Total RNA extraction and quantity control. Two pairs of cells were prepared for gene chip hybridization analysis: HE4-overexpressing cells vs. HE4-overexpressing vector cells, and HE4-shRNA cells vs. HE4-shRNA vector cells. Total RNA was extracted from all cell lines using RNeasy Mini kit and further purified with RNeasy MinElute Cleanup columns (both from Qiagen, Valencia, CA, USA). RNA quantity and purity were assessed using NanoDrop ND-1000. Pass criteria for absorbance ratios were established as A260/A280 $\geq 1.8$ and A260/A230 $\geq 1$. RNA integrity number (RIN) values were ascertained using Agilent RNA 6000 Nano assay to determine RNA integrity. Pass criterion for RIN value was established at $\geq 6$. The RNA samples in each group are labeled in Table I. The total RNA of each cell line was allocated to 3 chips for further hybridization and analysis to decrease the experimental error.

Gene chip hybridization, data collection and enrichment analysis. Purified RNA samples were submitted to Human Whole Genome OneArray ${ }^{\circledR}$ (HOA6.1) with Phalanx hybridization buffer using Phalanx Hybridization System for microarray analysis. This array contains 30,275 DNA oligonucleotide probes, and each probe is a 60 -mer designed in the sense direction. Among the probes, 29,187 probes correspond to the annotated genes in RefSeq v38 and Ensembl v56 database. In addition, 1,088 control probes are also included. After $16 \mathrm{~h}$ of hybridization at $50^{\circ} \mathrm{C}$, non-specific binding targets were washed away by 3 different washing steps (wash I, $42^{\circ} \mathrm{C}$ for $5 \mathrm{~min}$; wash II, $42^{\circ} \mathrm{C}$ for $5 \mathrm{~min}, 25^{\circ} \mathrm{C}$ for $5 \mathrm{~min}$; and wash III, rinse 20 times), and the slides were dried by centrifugation 

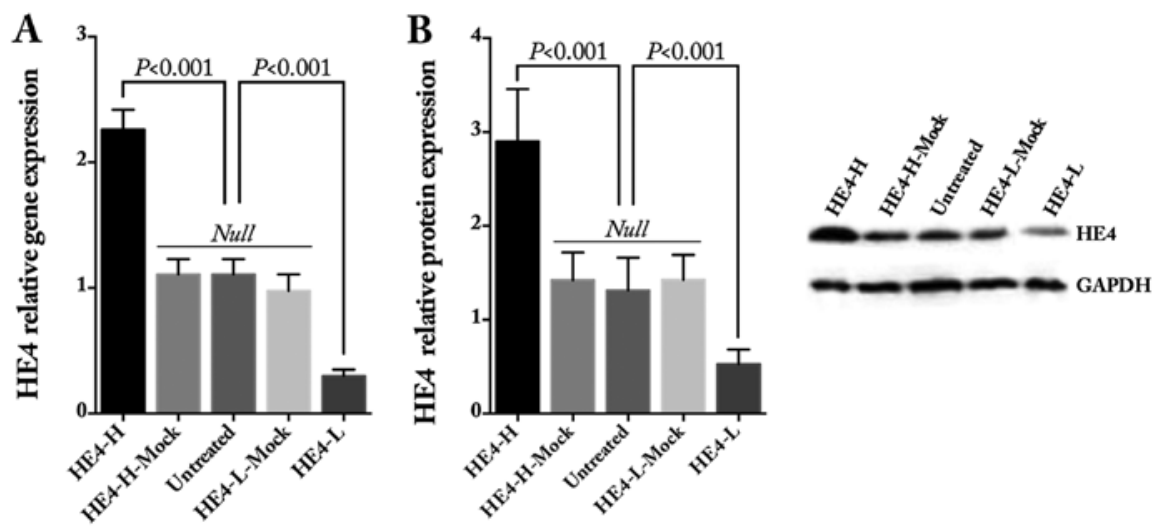

Figure 1. Verification of HE4 gene transfection. Quantitative real-time PCR results (A) and western blot analysis results (B) of the expression of HE4 after HE4 gene transfection (HE4-H, HE4 gene transfection; HE4-L, HE4 shRNA transfection) in ovarian cancer cell line ES-2, in which the data are quantitatively expressed as HE4 relative to GAPDH. The western blotting image in B is partly from our previously published study (23).

and scanned by Axon 4000B scanner (Molecular Devices, Sunnyvale, CA, USA). The intensities of each probe were obtained by GenePix 4.1 software (Molecular Devices). In the present study, 12 chips were used to compare the differentially expressed genes (DEGs). Scatter plots were conducted to show the repeatability of the expression signal between technical repeats. Histogram plots were made to show the fold-change distribution of all probes excluding control and flagged probes. Volcano plots were performed to visually show a distinguishable gene expression profile among samples. Venny-diagram was performed to identify the coordinated DEGs in response to HE4 (http://bioinfogp.cnb.csic.es/tools/venny/). Foldchanges were calculated by Rosetta Resolver 7.2 with error model adjusted by Amersham Pairwise Ration Builder for signal comparison of sample. Standard selection criteria to identify DEGs were as follows: i) $\log _{2}$ Ifold-changel $\geq 1$ and $\mathrm{P}<0.05$; ii) $\log _{2}$ ratios 'NA' and the differences in intensity between the two samples $\geq 1,000$.

Validation of gene expression by RT-PCR and immunohistochemical (IHC) staining

$R T$-PCR. RT-PCR was performed in triplicate with primer sets and probes that were specific for 4 selected genes that were found to be significantly differentially expressed: FOXA2, SERPIND1, BDKRD1 and IL1A. The methods are shown as above.

IHC. To validate the DEGs at the protein level, IHC staining in ovarian samples was conducted. In our previous studies, we established a group of ovarian paraffin-embedded samples (23) including 50 malignant, 27 borderline, 15 benign and 15 normal ovarian tissues. In view of the further investigation, SERPIND1 was selected for IHC staining in these samples and then compared with the expression of HE4. The working dilution for SERPIND1 (\#12741-1-AP; ProteinTech, Chicago, IL, USA) was 1:400. The staining of hepatic cancer samples was chosen as the positive control and omission of the primary antibody was designed as the negative control. The staining procedures were performed as previously described (23). Regarding the evaluation method, in brief, the presence of brown-colored granules on the cell membrane or in the cytoplasm was taken as a positive signal, and was classified according to color intensity as follows: not colored, light yellow, brown and tan were recorded as 0,1 , 2 and 3, respectively. A positive cell staining rate of $<5,5-25$, $26-50$ and $51-75 \%$, and $>75 \%$ were recorded as $0,1,2,3$ and 4. The final score was determined by multiplying the positive cell staining rate and the score values: $0-2$ was considered negative (-), 3-4 was (+), 5-8 was (++), and 9-12 was (+++). - and + were considered as low expression; ++ and +++ as high expression. Two observers evaluated the sections to control error. Survival analysis was performed on these patients. The overall survival (OS) time was defined from the date of surgery (earliest was in August 2008) to the date of death or the last follow-up (September, 2015).

Enrichment analysis of DEGs. All the DEGs in each pair group were prepared to run Gene Ontology (GO) and canonical pathways analyses (Biocarta and KEGG). Gene interaction networks were visualized by Cytoscape (25). The property of the network was analyzed with the plug-in network analysis.

Statistical analysis. Statistical analyses were performed using the SPSS program (version 22 for Mac; SPSS, Inc., Chicago, IL, USA) and GraphPad Prism 6 (version $6.0 \mathrm{~h}$ for Mac; GraphPad Prism Software Inc., San Diego, CA, USA). Chi-square and one-way ANOVA with LSD or Bonferroni post hoc test was used for comparison between $>2$ groups. The correlation coefficient R of SERPIND1 with HE4 was calculated by Spearman correlation analysis. Quantitative data are presented as mean $\pm \mathrm{SD}$. As to the analysis of quantitative RT-PCR result, the data are expressed as mean \pm SEM. Survival analysis was analyzed using Kaplan-Meier curves by log-rank test. A P-value of $<0.05$ was considered to indicate a statistically significant result.

\section{Results}

Identification of HE4 gene transfection. Stable transfected cell lines were established using the ES-2 cells. The gene and protein expression levels of HE4 were obviously increased after HE4 transfection and decreased after shRNA transfection, as detected by quantitative real-time PCR (Fig. 1A) and western blotting (Fig. 1B and C), whereas there was no statistical difference in regards to HE4 in the mock and untreated cells. 

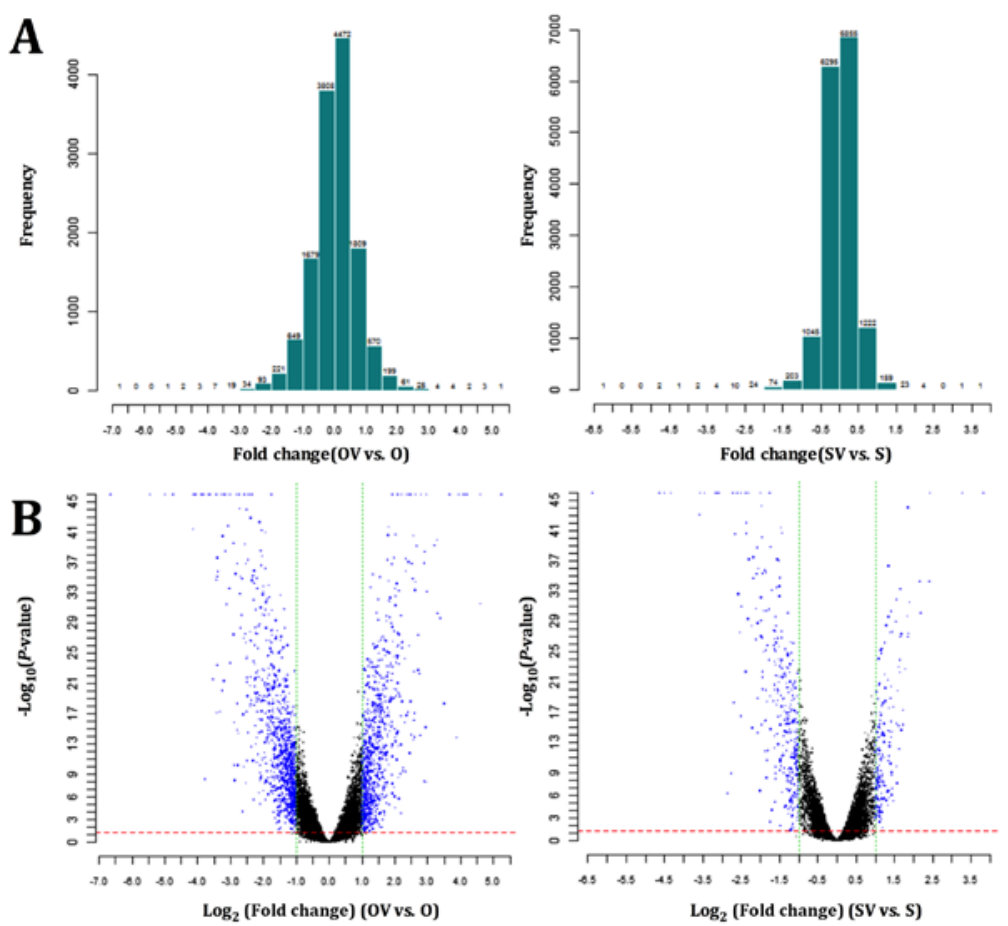

Figure 2. Histogram plots and volcano plots of the differentially expressed genes (DEGs). (A) Histogram plot shows fold-change distribution of all probes excluding control and flagged probes. (B) The volcano plot shows the distribution of differentially expressed probes while the dotted line in red and green represent the cut-off, a measurement of fold-change on the x-axis vs. a measure of significance (negative logarithm of the P-value) on the $y$-axis. The $\log ^{2}$ scales of the expression signal values were plotted for all probes excluding control and flagged probes. Standard selection criteria to identify DEGs are established at $\log _{2}$ Ifold-changel $\geq 1$ and $\mathrm{P}<0.05$ (blue dots in B). OV, HE4-H-vector; O, HE4-H; SV, HE4-L-vector; S, HE4-L cells.
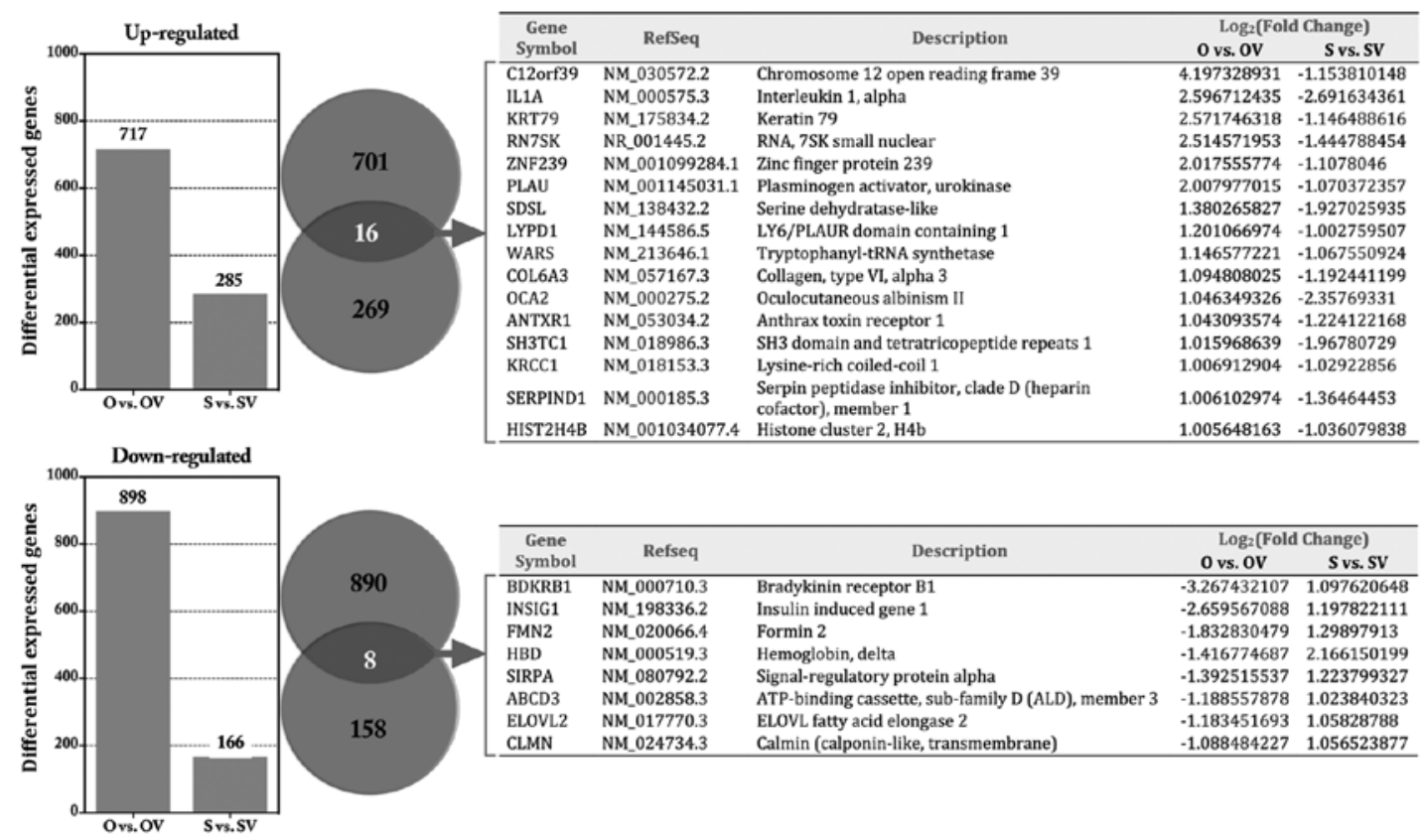

Figure 3. Venn-diagram analysis of the differentially expressed genes (DEGs). Venn diagrams of the DEGs generated from O vs. OV and S vs. SV. An overlap of 16 genes was consistently upregulated and 8 genes downregulated in response to HE4. OV, HE4-H-vector; O, HE4-H; SV, HE4-L-vector; S, HE4-L cells.

Gene expression analysis and clustering. The expression profiles of all the samples passed the microarray quality control (Table I). Histogram plots of fold-change distribution of all probes excluding control and flagged probes were conducted for all signals collected (Fig. 2A), and the volcano plots revealed the DEGs for each pair of gene chips (Fig. 2B).
A total of 717 genes were upregulated and 898 genes were downregulated in $\mathrm{O}$ vs. OV, 166 genes were upregulated and 285 were downregulated in S vs. SV. The top 20 DEGs in each group are shown in Table II. Venn diagrams showed that an overlap of 16 genes was consistently upregulated and 8 genes downregulated in response to HE4 (Fig. 3). 
Table II. Top 20 differentially expressed genes in each group.

\begin{tabular}{|c|c|c|c|c|}
\hline Gene symbol & RefSeq & Description & $\mathrm{og}_{2}$ (fold-change) & P-value \\
\hline \multicolumn{5}{|c|}{ O vs. OV upregulated } \\
\hline EPB41L3 & NM 012307.2 & Erythrocyte membrane protein band 4.1-like 3 & 5.246232 & 0 \\
\hline FOXA2 & NM 153675.2 & Forkhead box A2 & 4.619921 & $3.02 \mathrm{E}-32$ \\
\hline GDF15 & NM 004864.2 & Growth differentiation factor 15 & 4.612066 & 0 \\
\hline TAGLN3 & NM 001008273.1 & Transgelin 3 & 4.603976 & 0 \\
\hline C12orf39 & NM 030572.2 & Chromosome 12 open reading frame 39 & 4.197329 & 0 \\
\hline MMP3 & NM 002422.3 & Matrix metallopeptidase 3 & 3.961772 & 0 \\
\hline IL11 & NM 000641.3 & Interleukin 11 & 3.887501 & $1.55 \mathrm{E}-14$ \\
\hline IL24 & NM 001185158.1 & Interleukin 24 & 3.674028 & 0 \\
\hline FAM24B & NM 152644.2 & Family with sequence similarity 24 , member B & 3.390164 & $2.4 \mathrm{E}-30$ \\
\hline PPP1R15A & NM 014330.3 & Protein phosphatase 1 , regulatory subunit 15A & 3.31736 & $5.28 \mathrm{E}-31$ \\
\hline EGR1 & NM 001964.2 & Early growth response 1 & 3.217277 & $5.29 \mathrm{E}-40$ \\
\hline PHLDA1 & NM 007350.3 & Pleckstrin homology-like domain, family A, member 1 & 12.992293 & $8.23 \mathrm{E}-34$ \\
\hline LIF & NM 001257135.1 & Leukemia inhibitory factor & 2.973342 & 0 \\
\hline DUSP5 & NM 004419.3 & Dual specificity phosphatase 5 & 2.954481 & $6.36 \mathrm{E}-16$ \\
\hline SESN2 & NM 031459.4 & Sestrin 2 & 2.920611 & $3.56 \mathrm{E}-39$ \\
\hline BCL2A1 & NM 001114735.1 & BCL2-related protein A1 & 2.911151 & 8.87039E-09 \\
\hline HECW2 & NM 020760.1 & $\begin{array}{l}\mathrm{HECT}, \mathrm{C} 2 \text { and } \mathrm{WW} \text { domain containing } 2 \\
\text { E3 ubiquitin protein ligase }\end{array}$ & 2.90343 & $1.25 \mathrm{E}-37$ \\
\hline ALOX5AP & NM 001204406.1 & Arachidonate 5-lipoxygenase-activating protein & 2.801388 & 0 \\
\hline SAT1 & NM 002970.2 & Spermidine/spermine N1-acetyltransferase 1 & 2.785946 & $7.82 \mathrm{E}-15$ \\
\hline FES & NM 001143785.1 & Feline sarcoma oncogene & 2.75507 & $5.74 \mathrm{E}-23$ \\
\hline \multicolumn{5}{|c|}{ O vs. OV downregulated } \\
\hline NNMT & NM 006169.2 & Nicotinamide N-methyltransferase & -6.64385619 & 0 \\
\hline MAGED4B & NM 177535.2 & Melanoma antigen family D, 4B & -5.441719409 & 0 \\
\hline CCL2 & NM 002982.3 & Chemokine (C-C motif) ligand 2 & -4.986829225 & 0 \\
\hline IGFBP7 & NM 001253835.1 & Insulin-like growth factor binding protein 7 & -4.130075866 & $3.86 \mathrm{E}-42$ \\
\hline HSPA1A & NM 005345.5 & Heat shock $70 \mathrm{kDa}$ protein $1 \mathrm{~A}$ & -4.10938341 & 0 \\
\hline EMR1 & NM 001256255.1 & $\begin{array}{l}\text { EGF-like module containing, mucin-like, } \\
\text { hormone receptor-like } 1\end{array}$ & -4.046957637 & 0 \\
\hline SKP2 & NM 001243120.1 & $\begin{array}{l}\text { S-phase kinase-associated protein } 2 \\
\text { E3 ubiquitin protein ligase }\end{array}$ & -3.898911693 & 0 \\
\hline PDE5A & NM 001083.3 & Phosphodiesterase 5A, cGMP-specific & -3.855490571 & 0 \\
\hline CD70 & NM 001252.3 & CD70 molecule & -3.819833892 & 0 \\
\hline CFI & NM 000204.3 & Complement factor I & -3.766459211 & 5.14012E-09 \\
\hline LIMS3 & NM 033514.4 & LIM and senescent cell antigen-like domains 3 & -3.651045231 & 0 \\
\hline SSX3 & NM 021014.2 & Synovial sarcoma, $\mathrm{X}$ breakpoint 3 & -3.618755791 & 0 \\
\hline IFITM1 & NM 003641.3 & Interferon-induced transmembrane protein 1 & -3.525679252 & $3.07 \mathrm{E}-22$ \\
\hline KIF20A & NM 005733.2 & Kinesin family member $20 \mathrm{~A}$ & -3.419799073 & 0 \\
\hline SSX1 & NM 005635.2 & Synovial sarcoma, $\mathrm{X}$ breakpoint 1 & -3.419729777 & $2.21 \mathrm{E}-35$ \\
\hline HLA-DRB1 & NM 002124.3 & Major histocompatibility complex, class II, DR $\beta 1$ & -3.405215808 & $8.44 \mathrm{E}-18$ \\
\hline BTN3A2 & NM 001197247.1 & Butyrophilin, subfamily 3 , member A2 & -3.397469936 & $2.41 \mathrm{E}-38$ \\
\hline SERPINA5 & NM 000624.5 & Serpin peptidase inhibitor, clade A, member 5 & -3.39163364 & 7.73E-36 \\
\hline CA12 & NM 206925.1 & Carbonic anhydrase XII & -3.389182356 & $3.73 \mathrm{E}-24$ \\
\hline TCAM1P & NR 002947.2 & Testicular cell adhesion molecule 1 , pseudogene & -3.373389711 & $1.8 \mathrm{E}-36$ \\
\hline \multicolumn{5}{|c|}{ S vs. SV upregulated } \\
\hline NOP56 & NR 027700.2 & NOP56 ribonucleoprotein & 3.826358 & 0 \\
\hline BST1 & NM 004334.2 & Bone marrow stromal cell antigen 1 & 3.284546 & 0 \\
\hline MMP3 & NM 002422.3 & Matrix metallopeptidase 3 & 2.436151 & 0 \\
\hline PTPRB & NM 001206972.1 & Protein tyrosine phosphatase, receptor type, B & 2.425614 & 4.99E-35 \\
\hline PHYHD1 & NM 001100877.1 & Phytanoyl-CoA dioxygenase domain containing 1 & 2.201466 & 7.67E-31 \\
\hline HBD & NM 000519.3 & Hemoglobin, $\delta$ & 2.16615 & $5.78 \mathrm{E}-35$ \\
\hline
\end{tabular}


Table II. Continued.

\begin{tabular}{|c|c|c|c|c|}
\hline Gene symbol & RefSeq & Description & $\operatorname{Lg}_{2}$ (fold-change) & P-value \\
\hline PTPRR & NM 001207016.1 & Protein tyrosine phosphatase, receptor type, $\mathrm{R}$ & 1.895908 & $2.74 \mathrm{E}-32$ \\
\hline MAVS & NM 001206491.1 & Mitochondrial antiviral signaling protein & 1.864901 & $8.41 \mathrm{E}-45$ \\
\hline NGF & NM 002506.2 & Nerve growth factor ( $\beta$ polypeptide $)$ & 1.864624 & $9.83 \mathrm{E}-28$ \\
\hline CDH13 & NM 001220490.1 & Cadherin 13, H-cadherin (heart) & 1.847737 & $2.15 \mathrm{E}-30$ \\
\hline HSPA12A & NM 025015.2 & Heat shock $70 \mathrm{kDa}$ protein $12 \mathrm{~A}$ & 1.790451 & $1.94 \mathrm{E}-23$ \\
\hline CTAG1B & NM 001327.2 & Cancer/testis antigen 1B & 1.739519 & $5.56 \mathrm{E}-18$ \\
\hline AK5 & NM 174858.2 & Adenylate kinase 5 & 1.691767 & 4.62E-28 \\
\hline OR6F1 & NM 001005286.1 & Olfactory receptor, family 6 , subfamily $\mathrm{F}$, member 1 & 1.68494 & $2.46 \mathrm{E}-15$ \\
\hline CDH13 & NM 001220490.1 & Cadherin 13, H-cadherin (heart) & 1.657027 & $9.68 \mathrm{E}-28$ \\
\hline PHYHD1 & NM 001100877.1 & Phytanoyl-CoA dioxygenase domain containing 1 & 1.650218 & $5.27 \mathrm{E}-23$ \\
\hline KRT15 & NM 002275.3 & Keratin 15 & 1.645917 & $1.26 \mathrm{E}-24$ \\
\hline RFX8 & NM 001145664.1 & RFX family member 8 , lacking RFX DNA binding domain & in 1.633169 & $7.81 \mathrm{E}-13$ \\
\hline SIGLEC15 & NM 213602.2 & Sialic acid binding Ig-like lectin 15 & 1.620068 & $1.14 \mathrm{E}-23$ \\
\hline QKI & NM 206855.2 & QKI, KH domain containing, RNA binding & 1.613219543 & $6.66 \mathrm{E}-16$ \\
\hline \multicolumn{5}{|c|}{ S vs. SV Downregulated } \\
\hline NNMT & NM 006169.2 & Nicotinamide N-methyltransferase & -6.370382878 & 0 \\
\hline HLA-DRB1 & NM 002124.3 & Major histocompatibility complex, class II, DR $\beta 1$ & -4.621376308 & 0 \\
\hline MAGEC2 & NM 016249.3 & Melanoma antigen family $\mathrm{C}, 2$ & -4.325342586 & 0 \\
\hline CSAG1 & NM 001102576.1 & Chondrosarcoma-associated gene 1 & -3.583955305 & $7.57 \mathrm{E}-44$ \\
\hline SERPINA5 & NM 000624.5 & Serpin peptidase inhibitor, clade A, member 5 & -3.57076951 & 0 \\
\hline EMR1 & NM 001256255.1 & $\begin{array}{l}\text { EGF-like module containing, mucin-like, } \\
\text { hormone receptor-like } 1\end{array}$ & -3.456673039 & 0 \\
\hline PSMB9 & NM 002800.4 & Proteasome (prosome, macropain) subunit, $\beta$ type, 9 & -3.165976101 & 0 \\
\hline CFI & NM 000204.3 & Complement factor I & -3.134811326 & 0 \\
\hline PAGE2 & NM 207339.2 & P-antigen family, member 2 (prostate-associated) & -3.072286145 & 0 \\
\hline CSAG1 & NM 001102576.1 & Chondrosarcoma-associated gene 1 & -2.848947621 & 5.84154E-07 \\
\hline SSX3 & NM 021014.2 & Synovial sarcoma, $\mathrm{X}$ breakpoint 3 & -2.753083201 & $1.24441 \mathrm{E}-09$ \\
\hline HLA-F & NM 001098478.1 & Major histocompatibility complex, class I, F & -2.715218223 & 0 \\
\hline BEX1 & NM 018476.3 & Brain expressed, $\mathrm{X}$-linked 1 & -2.707527614 & 0 \\
\hline IL1A & NM 000575.3 & Interleukin $1, \alpha$ & -2.691634361 & 0 \\
\hline PDGFRB & NM 002609.3 & Platelet-derived growth factor receptor, $\beta$ polypeptide & -2.673687033 & $6.05 \mathrm{E}-19$ \\
\hline NUPR1 & NM 001042483.1 & Nuclear protein, transcriptional regulator, 1 & -2.651204064 & $3.01 \mathrm{E}-41$ \\
\hline QPRT & NM 014298.3 & Quinolinate phosphoribosyltransferase & -2.59989928 & 0 \\
\hline PDE5A & NM 001083.3 & Phosphodiesterase 5A, cGMP-specific & -2.568004867 & $2.56 \mathrm{E}-33$ \\
\hline NDRG2 & NM 201541.1 & NDRG family member 2 & -2.525792745 & $2.63 \mathrm{E}-28$ \\
\hline CD70 & NM 001252.3 & CD70 molecule & -2.489739686 & 0 \\
\hline
\end{tabular}

Validation of gene expression results by $R T-P C R$. To validate the gene expression profile results, 4 DEGs (FOXA2, SERPIND1, BDKRD1 and IL1A) were selected for RT-PCR analysis verification (Fig. 4A). Generally, the trends for upregulation or downregulation of the DEGs by real-time PCR analysis were consistent with those of the DEG expression profiling analysis, confirming the reliability of the microarray results.

Validation of protein expression by IHC. Similar to HE4, the expression of SERPIND1 was mainly located on the membrane and in the cytoplasm (Fig. 4B). The positive expression rates of SERPIND1 in malignant, borderline, benign and normal ovarian tissues were 88, 62.96, 20 and
$13.33 \%$, respectively (Table III). Malignant groups displayed the highest positive expression and was significantly higher than the rate of the borderline $(\mathrm{P}=0.010)$, whereas the positive expression rate in the borderline groups was markedly higher than that in the benign groups $(\mathrm{P}=0.008)$. In general, the expression pattern of SERPIND1 was similar to that of HE4 (up to $74.8 \%$ ). Among the 50 cases of ovarian cancer samples, a total of 37 cases simultaneously showed positive expression of both HE4 and SERPIND1 and 4 cases showed both negative expression (Table IV). Spearman correlation analysis revealed that the expression of SERPIND1 and HE4 was positively correlated $(\mathrm{R}=0.402, \mathrm{P}=0.003)$. Survival analysis revealed that high expression levels of both HE4 and SERPIND1 were significantly correlated with poor prognosis (Kaplan-Meier 


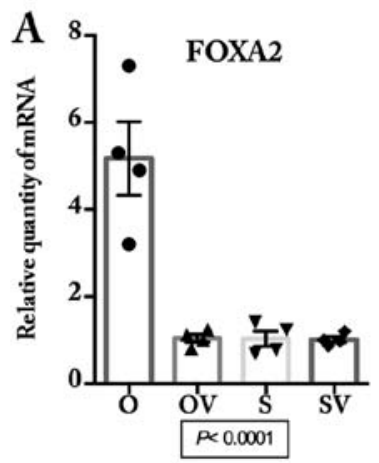

B

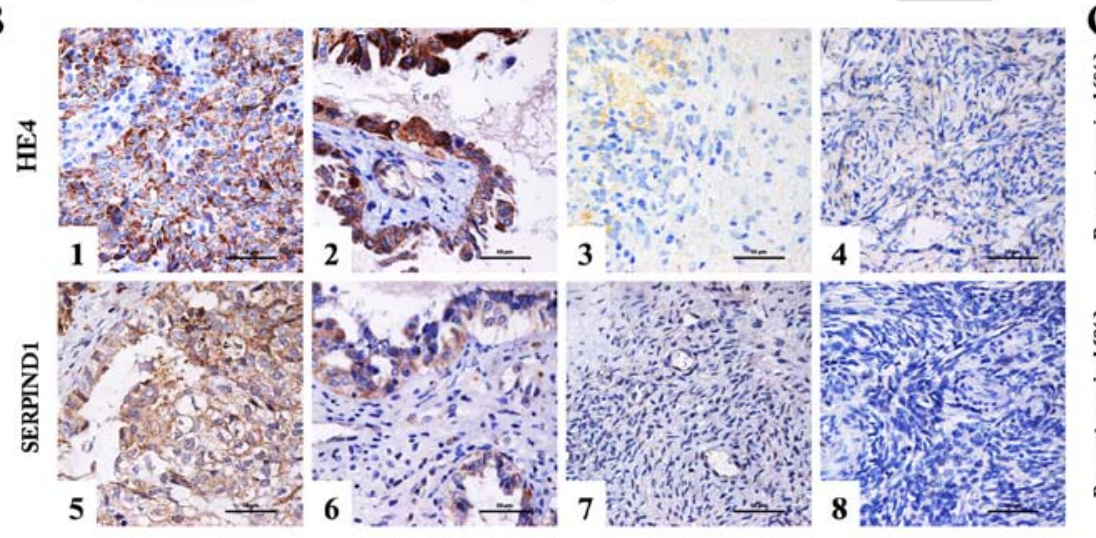

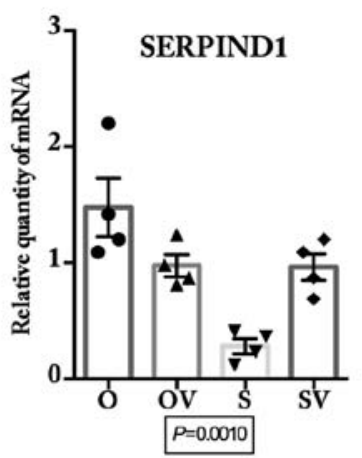

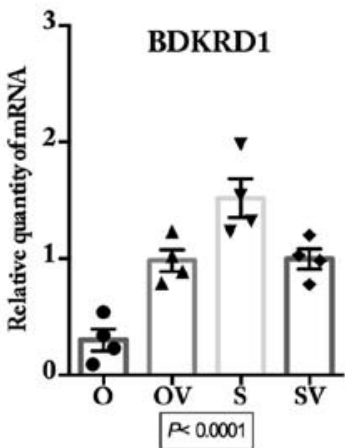

c
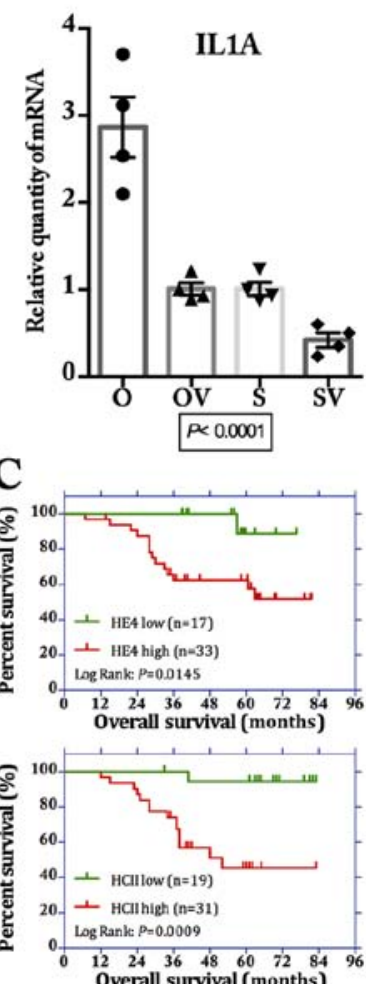

Figure 4. Validation of the differentially expressed genes. (A) Quantitative real-time PCR revealed that the mRNA expression levels of 4 selected genes (FOXA2, SERPIND1, BDKRD1 and IL1A) showed obvious difference among the 4 ovarian cancer cell lines (O, OV, $\mathrm{S}$ and $\mathrm{SV})$ (all $\mathrm{P}<0.01$, one-way ANOVA). (B) Immunohistochemical (IHC) staining for SERPIND1 showed a similar expression pattern with that of HE4 in the ovarian tissue samples. Representative images of IHC staining: ovarian malignant tumor (1 and 5), borderline tumor (2 and 6), benign tumor (3 and 7), and normal ovarian tissue (4 and 8 ) for staining of HE4 (1-4) and SERPIND1 (5-8). Scale bar, $50 \mu \mathrm{m}$. (C) Kaplan-Meier survival analysis showed that both high expression of HE4 and SERPIND1 were significantly correlated with poor overall survival for these 50 patients with ovarian malignant tumors (log-rank: $\mathrm{P}=0.0145$ and 0.009 for HE4 and SERPIND1, respectively). OV, HE4-H-vector; O, HE4-H; SV, HE4-L-vector; S, HE4-L cells.

A

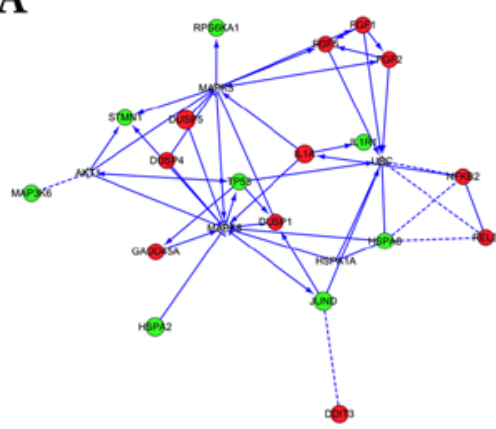

KEGG_MAPK_SIGNALING_PATHWAY

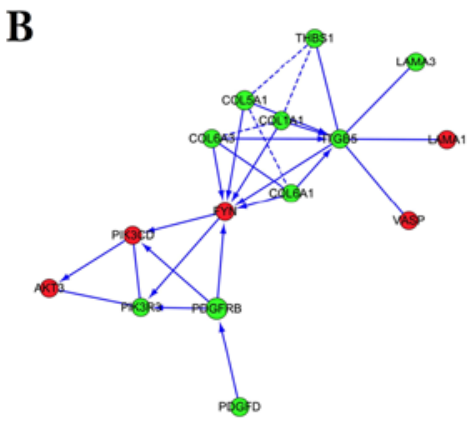

KEGG_FOCAL_ADHESION

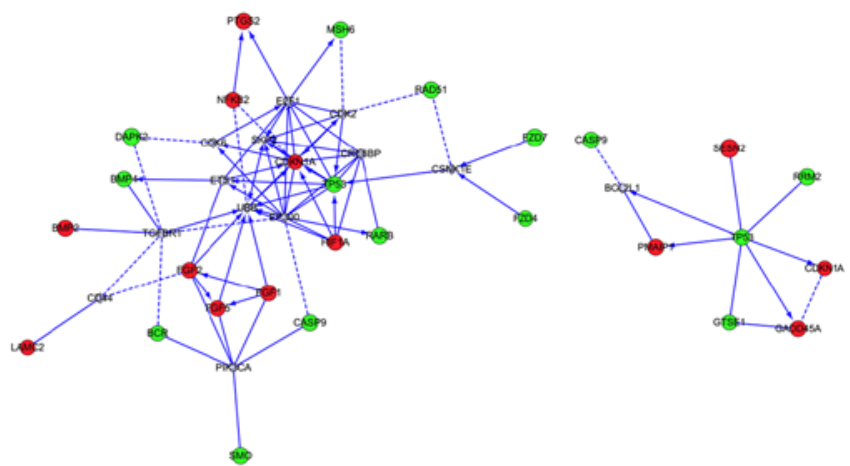

KEGG_PATHWAYS_IN_CANCER KEGG_P53_SIGNALING_PATHWAY

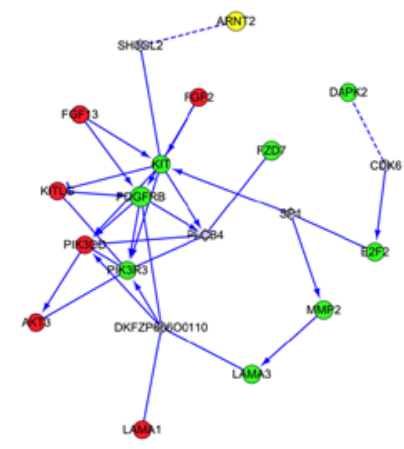

KEGG_PATHWAYS_IN_CANCER

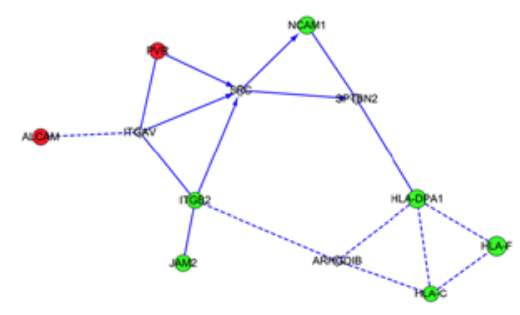

KEGG_CELL_ADHESION_MOLECULES_CAMS

Figure 5. Interaction networks of the differentially expressed genes (DEGs). The genes enriched in KEGG pathways in response to HE4 were determined by interaction network analysis. (A) Three pathways (MAPK signaling, pathways in cancer and p53 signaling) in the DEGs of O vs. OV and (B) 3 pathways (focal adhesion, pathways in cancer and cell adhesion molecules CAMs) in the DEGs of S vs. SV are shown. OV, HE4-H-vector; O, HE4-H; SV, HE4-L-vector; S, HE4-L cells. 
Table III. Expression of HE4 and HCII in different ovarian tissues.

\begin{tabular}{|c|c|c|c|c|c|c|c|c|c|c|c|c|c|}
\hline \multirow[b]{2}{*}{ Groups } & \multirow[b]{2}{*}{ Cases } & \multicolumn{6}{|c|}{ HE4 } & \multicolumn{6}{|c|}{ HCII } \\
\hline & & - & + & ++ & +++ & $\begin{array}{c}\text { Positive } \\
\text { cases }\end{array}$ & $\begin{array}{l}\text { Positive } \\
\text { rate }(\%)\end{array}$ & - & + & ++ & +++ & $\begin{array}{c}\text { Positive } \\
\text { cases }\end{array}$ & $\begin{array}{l}\text { Positive } \\
\text { rate }(\%)\end{array}$ \\
\hline Malignant & 50 & 11 & 6 & 16 & 17 & 39 & $78^{a}$ & 6 & 13 & 12 & 19 & 44 & $\mathbf{8 8}^{c}$ \\
\hline Borderline & 27 & 12 & 5 & 6 & 4 & 15 & $55.56^{b}$ & 10 & 6 & 6 & 5 & 17 & $62.96^{c}$ \\
\hline Benign & 15 & 12 & 3 & 0 & 0 & 3 & 20 & 12 & 1 & 1 & 1 & 3 & 20 \\
\hline Normal & 15 & 15 & 0 & 0 & 0 & 0 & 0 & 13 & 2 & 0 & 0 & 2 & 13.33 \\
\hline
\end{tabular}

${ }^{a}$ Compared with the borderline group, $\mathrm{P}=0.040$; ${ }^{\mathrm{b}}$ compared with the benign group, $\mathrm{P}=0.026$; ${ }^{\mathrm{c}}$ compared with the borderline group, $\mathrm{P}=0.010$; ${ }^{\mathrm{d}}$ compared with the benign group, $\mathrm{P}=0.008$. HE4, human epididymis protein 4; HCII, heparin co-factor II (SERPIND1).

analysis, log-rank, $\mathrm{P}=0.0145$ and $\mathrm{P}=0.0009$ as to $\mathrm{OS}$; Fig. $4 \mathrm{C}$, respectively).

GO function analysis and canonical pathway result of DEGs. GO analysis showed that all the DEGs in the different groups were predominantly involved in molecular function (MF), biological process (BP) and cellular component (CC), as shown in Table V. Canonical pathway analysis demonstrated that a total of 39 pathways were enriched in $\mathrm{O}$ vs. OV, and 50 pathways in S vs. SV. The top 20 pathways are shown in Table VI, such as MAPK signaling pathway, pathway in cancer and $\mathrm{P} 53$ signaling pathway in $\mathrm{O}$ vs. OV and focal adhesion, pathway in cancer and cell adhesion molecules (CAMs) in $\mathrm{S}$ vs. SV.

Interaction network for the DEGs. Three aforementioned pathways for the DEGs were selected to conduct interaction network analysis in 2 pairs, respectively (Fig. 5). Among the interaction networks, various interaction genes were predicted, such as MAPK3 and MAPK8 in MAPK signaling pathway, UBB and EP300 in pathways in cancer, SRC in cell adhesion molecules (CAMs) pathway, which appeared to be the connected predicted hub genes.

\section{Discussion}

The mortality rate of ovarian cancer patients ranks first among all gynecological malignant tumors, and up to $75 \%$ of diagnosed patients are already at an advanced stage. The early detection of ovarian cancer is difficult due to its indefinite symptoms in the early stage and lack of a specific marker; meanwhile, a poor understanding of the mechanisms of oncogenesis also impedes the development of new treatment modalities. In recent years, HE4 has drawn extensive attention in the study of ovarian cancer, due to its potential clinical application benefits for early detection (5), discrimination (6), better tumor cytoreductive surgery (8), chemoresistance and prognosis $(9,11)$. Moreover, it was also reported to be a reliable marker for early diagnosis of endometrial (12), lung (14) and pancreatic cancer (15). Thus, increasing research on the clinical application of HE4 stimulated elucidation of the basic mechanisms of its function. Unfortunately, relevant research
Table IV. Relevance of HE4 and HCII expression in ovarian cancer samples.

\begin{tabular}{lccc}
\hline & \multicolumn{2}{c}{ HCII } & \\
\cline { 2 - 3 } HE4 & Negative & Positive & Total \\
\hline Negative & 4 & 7 & 11 \\
Positive & 2 & 37 & 39 \\
Total & 6 & 44 & 50 \\
\hline
\end{tabular}

HE4, human epididymis protein 4; HCII, heparin co-factor II (SERPIND1).

is far from enough. In the present study, by the use of human whole genome microarray detection, we investigated the gene expression profile in response to HE4 in epithelial ovarian cancer (EOC) cells. We identify a total of 717 genes that were upregulated and 898 genes that were downregulated in HE4-overexpressing cells vs. HE4-Mock and 166 genes were upregulated and 285 were downregulated in the HE4-silenced cells vs. HE4-Mock cells. Furthermore, an overlap of 16 genes was consistently upregulated and 8 genes downregulated in response to HE4. The result was validated at the mRNA and protein levels. GO and pathway enrichment analysis were applied. Multiple pathways are involved, including KEGG MAPK signaling pathway, KEGG steroid biosynthesis, and KEGG pathways in cancer. Finally, interaction network plots were constructed and interactive genes were predicted. The known functions of these genes can provide novel ideas and breakthrough points for further research.

SERPIND1, also known as heparin co-factor II (HCII or HC2), attracted our attention. HCII belongs to the serpin superfamily and it is a serum glycoprotein that acts as a thrombin inhibitor through interactions with heparin and other endogenous glycosaminoglycans (26). Over the past 3 decades, $\mathrm{HCII}$ has been intermittently studied as a protease inhibitor. It can inhibit thrombin in atherosclerotic lesions where thrombin can exert a proatherogenic inflammatory response (27). It has also been proposed to promote angiogenesis in response to ischaemia (28). However, to date, the biological effect of 
Table V. GO enrichment analysis for differentially expressed genes (DEGs).

\begin{tabular}{|c|c|c|c|c|}
\hline GO terms & Genes in gene set & Genes in overlap & P-value & FDR q-val \\
\hline \multicolumn{5}{|l|}{ Molecular function } \\
\hline \multicolumn{5}{|l|}{ (Top 10 in $\mathrm{O}$ vs. OV) } \\
\hline Enzyme binding & 178 & 15 & $1.12 \mathrm{E}-09$ & $2.62 \mathrm{E}-07$ \\
\hline Transcription factor binding & 307 & 19 & $1.32 \mathrm{E}-09$ & $2.62 \mathrm{E}-07$ \\
\hline DNA binding & 602 & 26 & 2.92E-09 & $3.86 \mathrm{E}-07$ \\
\hline Transcription repressor activity & 152 & 12 & $1.07 \mathrm{E}-07$ & $1.06 \mathrm{E}-05$ \\
\hline Transcription cofactor activity & 228 & 14 & $2.16 \mathrm{E}-07$ & $1.71 \mathrm{E}-05$ \\
\hline Receptor binding & 377 & 17 & 8.97E-07 & $5.92 \mathrm{E}-05$ \\
\hline Receptor activity & 583 & 20 & $6.62 \mathrm{E}-06$ & $3.62 \mathrm{E}-04$ \\
\hline Transcription corepressor activity & 94 & 8 & 8.23E-06 & $3.62 \mathrm{E}-04$ \\
\hline Transcription factor activity & 354 & 15 & 8.24E-06 & $3.62 \mathrm{E}-04$ \\
\hline Transmembrane receptor activity & 418 & 16 & $1.47 \mathrm{E}-05$ & $5.81 \mathrm{E}-04$ \\
\hline \multicolumn{5}{|l|}{ (Top 10 in S vs. SV) } \\
\hline Receptor activity & 583 & 20 & $6.29 \mathrm{E}-08$ & $2.49 \mathrm{E}-05$ \\
\hline Phosphoric ester hydrolase activity & 153 & 10 & 4.64E-07 & $9.18 \mathrm{E}-05$ \\
\hline Transmembrane receptor activity & 418 & 15 & $1.63 \mathrm{E}-06$ & $1.57 \mathrm{E}-04$ \\
\hline Peptidase activity & 176 & 10 & $1.67 \mathrm{E}-06$ & $1.57 \mathrm{E}-04$ \\
\hline Hydrolase activity acting on ester bonds & 269 & 12 & $1.98 \mathrm{E}-06$ & $1.57 \mathrm{E}-04$ \\
\hline Endopeptidase activity & 117 & 8 & 4.71E-06 & $3.02 \mathrm{E}-04$ \\
\hline Enzyme inhibitor activity & 119 & 8 & $5.35 \mathrm{E}-06$ & $3.02 \mathrm{E}-04$ \\
\hline Protein kinase binding & 62 & 6 & $1.02 \mathrm{E}-05$ & $5.04 \mathrm{E}-04$ \\
\hline Protein kinase regulator activity & 39 & 5 & $1.42 \mathrm{E}-05$ & $6.24 \mathrm{E}-04$ \\
\hline Kinase binding & 70 & 6 & $2.06 \mathrm{E}-05$ & $8.15 \mathrm{E}-04$ \\
\hline Cell cycle GO 0007049 & 315 & 22 & $6.29 \mathrm{E}-12$ & $6.49 \mathrm{E}-10$ \\
\hline Cell proliferation GO 0008283 & 513 & 27 & $1.85 \mathrm{E}-11$ & $1.53 \mathrm{E}-09$ \\
\hline Protein metabolic process & 1,231 & 43 & $1.85 \mathrm{E}-11$ & $1.53 \mathrm{E}-09$ \\
\hline
\end{tabular}

Cellular component

(Top 10 in O vs. OV)

Nucleus

1,430

Cytoplasm

Extracellular region

Membrane

Extracellular region part

Membrane part

Extracellular space

Intracellular non membrane bound organelle

Non membrane bound organelle

Nuclear part

2,131

447

1,994

338

1,670

245

631

631

579

(Top 10 in S vs. SV)

Membrane

1,994

Membrane part

Extracellular region

Cytoplasm

Intrinsic to membrane

Plasma membrane

Integral to membrane

Extracellular region part

Plasma membrane part

Nucleus
1,670

447

2,131

1,348

1,426

1,330

338

1,158

1,430
54

62

23

53

19

46

16

25

25

22

53

43

22

49

36

37

35

15

28

29
6.66E-15

4.27E-12

$9.06 \mathrm{E}-10$

$1.65 \mathrm{E}-09$

6.40E-09

7.31E-09

$1.25 \mathrm{E}-08$

3.19E-08

3.19E-08

4.33E-07

$1.55 \mathrm{E}-14$

$1.65 \mathrm{E}-11$

$1.67 \mathrm{E}-11$

3.02E-11

3.14E-10

3.87E-10

8.24E-10

$1.12 \mathrm{E}-07$

2.44E-07

4.89E-06
$1.55 \mathrm{E}-12$

4.97E-10

7.04E-08

9.64E-08

2.84E-07

$2.84 \mathrm{E}-07$

4.15E-07

8.25E-07

8.25E-07

9.83E-06

3.62E-12

1.30E-09

1.30E-09

$1.76 \mathrm{E}-09$

$1.46 \mathrm{E}-08$

1.50E-08

2.74E-08

3.27E-06

6.32E-06

$1.05 \mathrm{E}-04$ 
Table V. Continued.

\begin{tabular}{|c|c|c|c|c|}
\hline GO terms & Genes in gene set & Genes in overlap & P-value & FDR q-value \\
\hline \multicolumn{5}{|l|}{ Biological process } \\
\hline \multicolumn{5}{|l|}{ (Top 10 in $\mathrm{O}$ vs. OV) } \\
\hline Biopolymer metabolic process & 1,684 & 63 & $0.00 \mathrm{E}+00$ & $0.00 \mathrm{E}+00$ \\
\hline Programmed cell death & 432 & 31 & $1.11 \mathrm{E}-16$ & $3.05 \mathrm{E}-14$ \\
\hline Apoptosis GO & 431 & 31 & $1.11 \mathrm{E}-16$ & $3.05 \mathrm{E}-14$ \\
\hline Cell development & 577 & 34 & $1.67 \mathrm{E}-15$ & $3.43 \mathrm{E}-13$ \\
\hline $\begin{array}{l}\text { Nucleobase nucleoside nucleotide and } \\
\text { nucleic acid metabolic process }\end{array}$ & 1,244 & 49 & $7.66 \mathrm{E}-15$ & $1.26 \mathrm{E}-12$ \\
\hline Multicellular organismal development & 1,049 & 41 & $1.74 \mathrm{E}-12$ & 2.39E-10 \\
\hline Response to stress & 508 & 28 & $2.62 \mathrm{E}-12$ & $3.08 \mathrm{E}-10$ \\
\hline Cell cycle GO 0007049 & 315 & 22 & $6.29 \mathrm{E}-12$ & $6.49 \mathrm{E}-10$ \\
\hline Cell proliferation GO 0008283 & 513 & 27 & $1.85 \mathrm{E}-11$ & $1.53 \mathrm{E}-09$ \\
\hline Protein metabolic process & 1,231 & 43 & $1.85 \mathrm{E}-11$ & $1.53 \mathrm{E}-09$ \\
\hline \multicolumn{5}{|l|}{ (Top 10 in S vs. SV) } \\
\hline Signal transduction & 1,634 & 45 & $5.53 \mathrm{E}-13$ & $4.57 \mathrm{E}-10$ \\
\hline Multicellular organismal development & 1,049 & 34 & $6.25 \mathrm{E}-12$ & $2.58 \mathrm{E}-09$ \\
\hline Response to chemical stimulus & 314 & 17 & $8.24 \mathrm{E}-10$ & $1.99 \mathrm{E}-07$ \\
\hline Anatomical structure development & 1,013 & 30 & $9.64 \mathrm{E}-10$ & $1.99 \mathrm{E}-07$ \\
\hline System development & 861 & 27 & $2.05 \mathrm{E}-09$ & $2.91 \mathrm{E}-07$ \\
\hline $\begin{array}{l}\text { Nucleobase nucleoside nucleotide } \\
\text { and nucleic acid metabolic process }\end{array}$ & 1,244 & 33 & 2.12E-09 & 2.91E-07 \\
\hline Biopolymer metabolic process & 1,684 & 39 & $3.07 \mathrm{E}-09$ & $3.62 \mathrm{E}-07$ \\
\hline Negative regulation of biological process & 677 & 23 & 7.63E-09 & $7.87 \mathrm{E}-07$ \\
\hline Negative regulation of cellular process & 646 & 22 & $1.56 \mathrm{E}-08$ & $1.43 \mathrm{E}-06$ \\
\hline Immune response & 235 & 13 & $6.34 \mathrm{E}-08$ & $5.23 \mathrm{E}-06$ \\
\hline
\end{tabular}

GO, Gene Ontology; DEGs, differentially expressed genes; FDR, false discovery rate; OV, HE4-H-vector; O, HE4-H; SV, HE4-L-vector; S, HE4-L cells.

HCII on cancer occurrence and development is still largely unknown, particularly in ovarian cancer. One group reported that high HCII expression in tumor tissues was associated with increased cancer recurrence and shorter OS in non-small cell lung cancer (NSCLC) patients. HCII promoted cell motility, invasion ability and filopodium dynamics in NSCLC cells partly through the PI3K pathway (29). Recently, HCII was found to be upregulated in the serum samples of B-cell acute lymphoblastic leukemia (B-ALL) patients and it was identified as a candidate biomarker for early diagnosis of B-ALL (30). In the present study, we found that the positive expression rates of HCII in malignant, borderline, benign and normal ovarian tissues were $88,62.96,20$ and $13.33 \%$, respectively. The protein expression pattern of HCII was positively related to that of HE4 (Spearman coefficient ratio, $\mathrm{R}=0.402, \mathrm{P}=0.003$ ) and high expression of HCII was correlated with poor OS of ovarian cancer patients. HCII may act as a potential oncogene in the development of ovarian cancer. It seems to be the first study on its potential function in the tumorigenesis of ovarian cancer and sheds light on the possible application as a tumor biomarker or therapeutic target along with HE4. However, further investigations are needed to elucidate the underlying mechanism.
In our previous studies, we demonstrated that HE4 enhanced the proliferation, invasion and metastasis of ovarian cancer (20) partially via the interaction of Annexin A2 (23), and fuco-glycosylation may increase this effect $(24,31)$. A similar phenomenon was also noted in others studies $(18,19,21)$, even in endometrial $(32,33)$ and pancreatic cancer (33). Nevertheless, the underlying mechanisms of these phenomena warrant more discussion. One group reported that the expression of HE4 is associated with cell adhesion, migration and tumor growth via the activation of the EGFR-MAPK signaling pathway (18) in ovarian cancer cells. However, another group reported a controversial finding that HE4 may play a protective role in the progression of ovarian cancer by inhibiting cell proliferation, whereas they also speculated that this effect may be regulated by MAPK and PI3K/Akt signaling pathway. As to the influence of $\mathrm{HE} 4$ on the chemotherapeutic resistance in ovarian cancer, our previous study noted that the recombinant HE4 protein could repress carboplatin-induced apoptosis in ovarian cancer cells (22). Another group reported that HE4 overexpression promoted chemoresistance against cisplatin in an animal model leading to reduced survival rates (19). They further demonstrated that tumor microenvironment 
Table VI. Canonical pathway analysis in the differentially expressed genes (DEGs).

\begin{tabular}{|c|c|c|c|c|c|}
\hline Pathways & $\begin{array}{l}\text { Genes in } \\
\text { gene set }\end{array}$ & $\begin{array}{l}\text { Genes in } \\
\text { overlap }\end{array}$ & P-value & $\begin{array}{c}\text { FDR } \\
\text { q-value }\end{array}$ & Gene symbols \\
\hline \multicolumn{6}{|l|}{ O vs. OV overlap pathways } \\
\hline $\begin{array}{l}\text { KEGG MAPK signaling } \\
\text { pathway }\end{array}$ & 267 & 21 & $1.99 \mathrm{E}-12$ & $7.46 \mathrm{E}-10$ & $\begin{array}{l}\text { TP53, FGF2, FGF1, FGF5, NFKB2, } \\
\text { GADD45A, HSPA1A, RPS6KA1, IL1A, } \\
\text { IL1R1, HSPA1B, HSPA2, HSPA8, } \\
\text { DUSP1, MAP3K6, DDIT3, JUND, } \\
\text { DUSP4, DUSP5, RELB, STMN1 }\end{array}$ \\
\hline KEGG steroid biosynthesis & 17 & 8 & $3.70 \mathrm{E}-12$ & $7.46 \mathrm{E}-10$ & $\begin{array}{l}C Y P 27 B 1, D H C R 24, D H C R 7, E B P, \\
F D F T 1, L S S, S Q L E, T M 7 S F 2\end{array}$ \\
\hline KEGG pathways in cancer & 328 & 21 & $9.60 \mathrm{E}-11$ & $1.29 \mathrm{E}-08$ & $\begin{array}{l}\text { TP53, FGF2, FGF1, FGF5, NFKB2, } \\
C D K N 1 A, S K P 2, C A S P 9, H I F 1 A, \\
B M P 2, B M P 4, S M O, F Z D 4, F Z D 7, \\
R A D 51, P T G S 2, L A M C 2, R A R B, \\
D A P K 2, M S H 6, B C R\end{array}$ \\
\hline KEGG cell cycle & 128 & 12 & $1.57 \mathrm{E}-08$ & $1.58 \mathrm{E}-06$ & $\begin{array}{l}\text { TP53, GADD45A, CDKN1A,SKP2, } \\
P C N A, C D C 25 C, M C M 2, M C M 3, \\
M C M 5, C D K N 2 C, S M C 1 A, S M C 3\end{array}$ \\
\hline Biocarta caspase pathway & 23 & 6 & $1.28 \mathrm{E}-07$ & 8.59E-06 & $\begin{array}{l}\text { CASP9, DFFB, LMNA, } \\
\text { LMNB1, CASP2, CASP6 }\end{array}$ \\
\hline Biocarta p53 hypoxia pathway & 23 & 6 & $1.28 \mathrm{E}-07$ & 8.59E-06 & $\begin{array}{l}\text { TP53, GADD45A, HSPA1A, } \\
C D K N 1 A, \text { HIF } 1 A, \text { NFKBIB }\end{array}$ \\
\hline Biocarta p53 pathway & 16 & 5 & $5.52 \mathrm{E}-07$ & $3.18 \mathrm{E}-05$ & $\begin{array}{l}\text { TP53, GADD45A, CDKN1A, } \\
\text { PCNA, TIMP3 }\end{array}$ \\
\hline KEGG p53 signaling pathway & 69 & 8 & 7.81E-07 & $3.94 \mathrm{E}-05$ & $\begin{array}{l}\text { TP53, GADD45A, CDKN1A, CASP9, } \\
\text { RRM2, GTSE1, PMAIP1, SESN2 }\end{array}$ \\
\hline Biocarta G2 pathway & 24 & 5 & $5.00 \mathrm{E}-06$ & 2.24E-04 & $\begin{array}{l}\text { TP53, GADD45A, RPS6KA1, } \\
C D K N 1 A, C D C 25 C\end{array}$ \\
\hline KEGG basal cell carcinoma & 55 & 6 & $2.75 \mathrm{E}-05$ & $1.11 \mathrm{E}-03$ & TP53, BMP2, BMP4, SMO, FZD4, FZD7 \\
\hline Biocarta MCM pathway & 18 & 4 & $3.55 \mathrm{E}-05$ & $1.15 \mathrm{E}-03$ & $M C M 2, M C M 3, M C M 5, C D T 1$ \\
\hline $\begin{array}{l}\text { KEGG cytokine cytokine } \\
\text { receptor interaction }\end{array}$ & 267 & 12 & $3.70 \mathrm{E}-05$ & $1.15 \mathrm{E}-03$ & $\begin{array}{l}\text { IL1A,IL1R1, BMP2,IL12A, } \\
\text { INHBA, IL11, CCL2, CXCL2, } \\
\text { CXCL3, CXCL5, LIF ,IL24 }\end{array}$ \\
\hline Biocarta HIVNEF pathway & 58 & 6 & $3.73 \mathrm{E}-05$ & $1.15 \mathrm{E}-03$ & $\begin{array}{l}C A S P 9, D F F B, L M N A \\
L M N B 1, C A S P 2, C A S P 6\end{array}$ \\
\hline KEGG DNA replication & 36 & 5 & $3.99 \mathrm{E}-05$ & $1.15 \mathrm{E}-03$ & PCNA, MCM2, MCM3, MCM5, POLE2 \\
\hline Biocarta ATM pathway & 20 & 4 & $5.53 \mathrm{E}-05$ & $1.49 \mathrm{E}-03$ & TP53, GADD45A, CDKN1A, RAD51 \\
\hline $\begin{array}{l}\text { KEGG complement and } \\
\text { coagulation cascades }\end{array}$ & 69 & 6 & $1.00 \mathrm{E}-04$ & $2.52 \mathrm{E}-03$ & $\begin{array}{l}\text { PLAU, BDKRB } 1, \text { CFI, PLAUR, } \\
\text { SERPINA1, SERPINA5 }\end{array}$ \\
\hline Biocarta TNFR1 pathway & 29 & 4 & $2.51 \mathrm{E}-04$ & $5.95 \mathrm{E}-03$ & $D F F B, L M N A, L M N B 1, C A S P 2$ \\
\hline Biocarta FAS pathway & 30 & 4 & 2.87E-04 & $6.29 \mathrm{E}-03$ & $D F F B, L M N A, L M N B 1, C A S P 6$ \\
\hline KEGG small cell lung cancer & 84 & 6 & $2.96 \mathrm{E}-04$ & $6.29 \mathrm{E}-03$ & $\begin{array}{l}\text { TP53, SKP2, CASP9, } \\
P T G S 2, L A M C 2, R A R B\end{array}$ \\
\hline KEGG apoptosis & 88 & 6 & $3.81 \mathrm{E}-04$ & 7.66E-03 & TP53, IL1A, IL1R1, CASP9, DFFB, CASP6 \\
\hline \multicolumn{6}{|l|}{ S vs. SV overlap pathways } \\
\hline KEGG focal adhesion & 201 & 15 & $9.86 \mathrm{E}-11$ & $3.97 \mathrm{E}-08$ & $\begin{array}{l}\text { PDGFRB, PIK3CD, PIK3R3, AKT3, } \\
\text { LAMA3, LAMA1, PDGFD, ITGB5, } \\
\text { THBS1, COL1A1, COL5A1, COL6A1, } \\
\text { COL6A3, VASP, FYN }\end{array}$ \\
\hline KEGG pathways in cancer & 328 & 15 & 7.61E-08 & $1.02 \mathrm{E}-05$ & $\begin{array}{l}\text { PDGFRB, PIK3CD } P I K 3 R 3, A K T 3, \\
L A M A 3, L A M A 1, E 2 F 2, F G F 2, \\
F G F 13, K I T, K I T L G, M M P 2 \\
D A P K 2, A R N T 2, F Z D 7\end{array}$ \\
\hline
\end{tabular}


Table VI. Continued.

\begin{tabular}{|c|c|c|c|c|c|}
\hline Pathways & $\begin{array}{l}\text { Genes in } \\
\text { gene set }\end{array}$ & $\begin{array}{l}\text { Genes in } \\
\text { overlap }\end{array}$ & P-value & $\begin{array}{c}\text { FDR } \\
\text { q-value }\end{array}$ & Gene symbols \\
\hline $\begin{array}{l}\text { KEGG complement and } \\
\text { coagulation cascades }\end{array}$ & 69 & 8 & $8.04 \mathrm{E}-08$ & $1.02 \mathrm{E}-05$ & $\begin{array}{l}\text { BDKRB1, PLAU, F3, CD46, CFH, } \\
\text { CFI, SERPINA5, SERPIND1 }\end{array}$ \\
\hline KEGG melanoma & 71 & 8 & $1.01 \mathrm{E}-07$ & $1.02 \mathrm{E}-05$ & $\begin{array}{l}\text { PDGFRB }, P I K 3 C D, P I K 3 R 3, A K T 3, \\
P D G F D, E 2 F 2, F G F 2, F G F 13\end{array}$ \\
\hline $\begin{array}{l}\text { KEGG cytokine } \\
\text { cytokine receptor } \\
\text { interaction }\end{array}$ & 267 & 13 & 2.77E-07 & 2.23E-05 & $\begin{array}{l}\text { PDGFRB, KIT, KITLG, ILIA, } \\
\text { IL7R, ILAR, IL12A,IFNAR1, } \\
\text { CCL5, CCL20, CXCL5, } \\
\text { TNFSF } 12, \text { TNFSF4 }\end{array}$ \\
\hline $\begin{array}{l}\text { KEGG ECM receptor } \\
\text { interaction }\end{array}$ & 84 & 8 & $3.78 \mathrm{E}-07$ & $2.54 \mathrm{E}-05$ & $\begin{array}{l}\text { LAMA3, LAMA1, ITGB5, THBS1, } \\
\text { COL1A1, COL5A1,COL6A1,COL6A3 }\end{array}$ \\
\hline $\begin{array}{l}\text { KEGG hematopoietic } \\
\text { cell lineage }\end{array}$ & 88 & 7 & $6.88 \mathrm{E}-06$ & 3.74E-04 & $\begin{array}{l}K I T, K I T L G, I L 1 A, I L 7 R \\
I L 4 R, M M E, C D 9\end{array}$ \\
\hline KEGG prostate cancer & 89 & 7 & 7.42E-06 & 3.74E-04 & $\begin{array}{l}\text { PDGFRB }, \text { PIK } 3 C D, P I K 3 R 3, A K T 3, \\
P D G F D, E 2 F 2, C R E B 3 L 1\end{array}$ \\
\hline $\begin{array}{l}\text { KEGG regulation of } \\
\text { actin cytoskeleton }\end{array}$ & 216 & 10 & $1.03 \mathrm{E}-05$ & $4.59 \mathrm{E}-04$ & $\begin{array}{l}\text { PDGFRB, PIK3CD }, P I K 3 R 3, \text { PDGFD, } \\
\text { ITGB5, FGF2, FGF } 13, \\
\text { BDKRB1, ITGB2, GSN }\end{array}$ \\
\hline $\begin{array}{l}\text { KEGG cell adhesion CAMs } \\
\text { molecules }\end{array}$ & 134 & 8 & $1.28 \mathrm{E}-05$ & $5.16 \mathrm{E}-04$ & $\begin{array}{l}I T G B 2, H L A-C, H L A-D P A 1, H L A-F \\
J A M 2, N C A M 1, A L C A M, P V R\end{array}$ \\
\hline KEGG type I diabetes mellitus & 44 & 5 & $2.59 \mathrm{E}-05$ & $9.49 \mathrm{E}-04$ & IL1A, IL12A, HLA-C, HLA-DPA1, HLA-F \\
\hline $\begin{array}{l}\text { KEGG leukocyte } \\
\text { transendothelial migration }\end{array}$ & 118 & 7 & 4.66E-05 & $1.57 \mathrm{E}-03$ & $\begin{array}{l}P I K 3 C D, P I K 3 R 3, V A S P, M M P 2 \\
I T G B 2, J A M 2, N C F 2\end{array}$ \\
\hline KEGG small cell lung cancer & 84 & 6 & $5.81 \mathrm{E}-05$ & $1.80 \mathrm{E}-03$ & $\begin{array}{l}P I K 3 C D, P I K 3 R 3, A K T 3 \\
L A M A 3, L A M A 1, E 2 F 2\end{array}$ \\
\hline $\begin{array}{l}\text { KEGG natural killer } \\
\text { cell-mediated cytotoxicity }\end{array}$ & 137 & 7 & $1.20 \mathrm{E}-04$ & $3.44 \mathrm{E}-03$ & $\begin{array}{l}P I K 3 C D, P I K 3 R 3, F Y N, I F N A R 1, \\
I T G B 2, H L A-C, S H 2 D 1 B\end{array}$ \\
\hline KEGG prion diseases & 35 & 4 & $1.69 \mathrm{E}-04$ & $4.07 \mathrm{E}-03$ & $F Y N, I L 1 A, C C L 5, N C A M 1$ \\
\hline $\begin{array}{l}\text { KEGG TOLL-like receptor } \\
\text { signaling pathway }\end{array}$ & 102 & 6 & $1.71 \mathrm{E}-04$ & 4.07E-03 & $\begin{array}{l}P I K 3 C D, P I K 3 R 3, A K T 3 \\
I L 12 A, I F N A R 1, C C L 5\end{array}$ \\
\hline KEGG glioma & 65 & 5 & $1.72 \mathrm{E}-04$ & 4.07E-03 & $\begin{array}{l}P D G F R B, P I K 3 C D, P I K 3 R 3, \\
A K T 3, E 2 F 2\end{array}$ \\
\hline KEGG allograft rejection & 38 & 4 & 2.33E-04 & $5.23 \mathrm{E}-03$ & $I L 12 A, H L A-C, H L A-D P A 1, H L A-F$ \\
\hline $\begin{array}{l}\text { KEGG JAK-STAT signaling } \\
\text { pathway }\end{array}$ & 155 & 7 & $2.56 \mathrm{E}-04$ & $5.43 \mathrm{E}-03$ & $\begin{array}{l}P I K 3 C D, P I K 3 R 3, A K T 3, I L 7 R, \\
I L 4 R, I L 12 A, I F N A R 1\end{array}$ \\
\hline KEGG leishmania infection & 72 & 5 & $2.78 \mathrm{E}-04$ & $5.60 \mathrm{E}-03$ & $\begin{array}{l}\text { IL1A,IL12A, ITGB2 } \\
\text { HLA-DPA1,NCF2 }\end{array}$ \\
\hline
\end{tabular}

DEGs, differentially expressed genes; FDR, false discovery rate; OV, HE4-H-vector; O, HE4-H; SV, HE4-L-vector; S, HE4-L cells.

constituents participated in the modulation of HE4, in which HE4 could interact with EGFR, IGF1R and transcription factor HIF1 $\alpha$, inducing the nuclear translocation of HE4 to promote aggressive and chemoresistant disease and denote poor prognosis for ovarian cancer patients (19). Recently, a group reported that recombinant HE4 protein increased the mRNA and protein levels of cell cycle marker PCNA and cell cycle inhibitor p21 in endometrial and pancreatic cancer cell lines, indicating that HE4 function may be mediated by the p21-CDK-Rb pathway (33). In the present study, we presented the results for the possible pathways
HE4 may enrich, including MAPK, steroid biosynthesis, cell cycle, p53 hypoxia pathway, focal adhesion, ECM receptor interaction, and cell adhesion molecules (CAMs). To the best of our knowledge, this is the first study to provide the most detailed, full-scale and fundamental data for the DEGs in response to HE4, thus laying the basis for further investigation on the underlying mechanisms of HE4 in ovarian cancer. More comprehensive and in-depth studies are needed, to provide more evidence for the development of novel drugs and therapeutic strategies selectively targeting HE4 in ovarian cancer. 
Collectively, the present study analyzed the gene expression profile in response to HE4 in EOC cells. The identified DEGs are valuable to determine the underlying mechanism of HE4 in cancer, providing new views for the comprehensive study of ovarian cancer treatment. Prospective investigations using the identified DEGs are required to further elucidate the mechanisms of the tumorgenesis and development of ovarian cancer.

\section{Acknowledgements}

The present study was supported by the National Natural Science Foundation of China (grant nos. 81172491, 81101527, 81472437 and 81402129), the Education Department Doctor Project Fund (grant nos. 20112104110016 and 20112104120019), and the Outstanding Scientific Fund of Shengjing Hospital (grant no. 201303).

\section{References}

1. Siegel RL, Miller KD and Jemal A: Cancer statistics, 2016. CA Cancer J Clin 66: 7-30, 2016.

2. Pliarchopoulou K and Pectasides D: Epithelial ovarian cancer: Focus on targeted therapy. Crit Rev Oncol Hematol 79: 17-23, 2011.

3. Schummer M, Ng WV, Bumgarner RE, Nelson PS, Schummer B, Bednarski DW, Hassell L, Baldwin RL, Karlan BY and Hood L: Comparative hybridization of an array of 21,500 ovarian cDNAs for the discovery of genes overexpressed in ovarian carcinomas. Gene 238: 375-385, 1999.

4. Cornwall GA, von Horsten HH, Swartz D, Johnson S, Chau K and Whelly S: Extracellular quality control in the epididymis. Asian J Androl 9: 500-507, 2007.

5. Karlsen MA, Høgdall EV, Christensen IJ, Borgfeldt C, Kalapotharakos G, Zdrazilova-Dubska L, Chovanec J, Lok CA, Stiekema A, Mutz-Dehbalaie I, et al: A novel diagnostic index combining HE4, CA125 and age may improve triage of women with suspected ovarian cancer - An international multicenter study in women with an ovarian mass. Gynecol Oncol 138: 640-646, 2015

6. Romagnolo C, Leon AE, Fabricio AS, Taborelli M, Polesel J, Del Pup L, Steffan A, Cervo S, Ravaggi A, Zanotti L, et al: HE4, CA125 and risk of ovarian malignancy algorithm (ROMA) as diagnostic tools for ovarian cancer in patients with a pelvic mass: An Italian multicenter study. Gynecol Oncol 141: 303-311, 2016.

7. Wilailak S, Chan KK, Chen CA, Nam JH, Ochiai K, Aw TC, Sabaratnam S, Hebbar S, Sickan J, Schodin BA, et al: Distinguishing benign from malignant pelvic mass utilizing an algorithm with HE4, menopausal status, and ultrasound findings. J Gynecol Oncol 26: 46-53, 2015.

8. Chen WT, Gao X, Han XD, Zheng H, Guo L and Lu RQ: HE4 as a serum biomarker for ROMA prediction and prognosis of epithelial ovarian cancer. Asian Pac J Cancer Prev 15: 101-105, 2014.

9. Angioli R, Capriglione S, Aloisi A, Guzzo F, Luvero D, Miranda A, Damiani P, Montera R, Terranova C and Plotti F: Can HE4 predict platinum response during first-line chemotherapy in ovarian cancer? Tumour Biol 35: 7009-7015, 2014.

10. Vallius T, Hynninen J, Auranen A, Carpén O, Matomäki J, Oksa S, Virtanen J and Grénman S: Serum HE4 and CA125 as predictors of response and outcome during neoadjuvant chemotherapy of advanced high-grade serous ovarian cancer. Tumour Biol 35: 12389-12395, 2014.

11. Zhu LC, Gao J, Hu ZH, Schwab CL, Zhuang HY, Tan MZ, Yan LM, Liu JJ, Zhang DY and Lin B: Membranous expressions of Lewis y and CAM-DR-related markers are independent factors of chemotherapy resistance and poor prognosis in epithelial ovarian cancer. Am J Cancer Res 5: 830-843, 2015.

12. Kemik P, Saatli B, Yıldırım N, Kemik VD, Deveci B, Terek MC, Koçtürk S, Koyuncuoğlu M and Saygılı U: Diagnostic and prognostic values of preoperative serum levels of YKL-40, HE-4 and DKK-3 in endometrial cancer. Gynecol Oncol 140: 64-69, 2016.

13. Li X, Gao Y, Tan M, Zhuang H, Gao J, Hu Z, Wang H, Zhu L, Liu J and Lin B: Expression of HE4 in endometrial cancer and its clinical significance. Biomed Res Int 2015: 437468, 2015.
14. Jiang Y, Wang C, Lv B, Ma G and Wang L: Expression level of serum human epididymis 4 and its prognostic significance in human non-small cell lung cancer. Int J Clin Exp Med 7: 5568-5572, 2014.

15. Huang T, Jiang SW, Qin L, Senkowski C, Lyle C, Terry K, Brower S, Chen H, Glasgow W, Wei Y, et al: Expression and diagnostic value of HE4 in pancreatic adenocarcinoma. Int J Mol Sci 16: 2956-2970, 2015.

16. Lan WG, Hao YZ, Xu DH, Wang P, Zhou YL and Ma LB: Serum human epididymis protein 4 is associated with the treatment response of concurrent chemoradiotherapy and prognosis in patients with locally advanced non-small cell lung cancer. Clin Transl Oncol 18: 375-380, 2016.

17. Lamy PJ, Plassot C and Pujol JL: Serum HE4: An independent prognostic factor in non-small cell lung cancer. PLoS One 10: e0128836, 2015

18. Lu R, Sun X, Xiao R, Zhou L, Gao X and Guo L: Human epididymis protein 4 (HE4) plays a key role in ovarian cancer cell adhesion and motility. Biochem Biophys Res Commun 419: 274-280, 2012.

19. Moore RG, Hill EK, Horan T, Yano N, Kim K, MacLaughlan S, Lambert-Messerlian G, Tseng YD, Padbury JF, Miller MC, et al: HE4 (WFDC2) gene overexpression promotes ovarian tumor growth. Sci Rep 4: 3574, 2014.

20. Zhu L, Zhuang H, Wang H, Tan M, Schwab CL, Deng L, Gao J, Hao Y, Li X, Gao S, et al: Overexpression of HE4 (human epididymis protein 4) enhances proliferation, invasion and metastasis of ovarian cancer. Oncotarget 7: 729-744, 2016.

21. Chen Y, Mu X, Wang S, Zhao L, Wu Y, Li J and Li M: WAP four-disulfide core domain protein 2 mediates the proliferation of human ovarian cancer cells through the regulation of growthand apoptosis-associated genes. Oncol Rep 29: 288-296, 2013.

22. Wang H, Zhu L, Gao J, Hu Z and Lin B: Promotive role of recombinant HE4 protein in proliferation and carboplatin resistance in ovarian cancer cells. Oncol Rep 33: 403-412, 2015.

23. Zhuang H, Tan M, Liu J, Hu Z, Liu D, Gao J, Zhu L and Lin B: Human epididymis protein 4 in association with Annexin II promotes invasion and metastasis of ovarian cancer cells. Mol Cancer 13: 243, 2014.

24. Zhuang H, Hu Z, Tan M, Zhu L, Liu J, Liu D, Yan L and Lin B: Overexpression of Lewis y antigen promotes human epididymis protein 4-mediated invasion and metastasis of ovarian cancer cells. Biochimie 105: 91-98, 2014.

25. Diaz-Montana JJ and Diaz-Diaz N: Development and use of the Cytoscape app GFD-Net for measuring semantic dissimilarity of gene networks. F1000Res 3: 142, 2014.

26. Tollefsen DM: Heparin cofactor II modulates the response to vascular injury. Arterioscler Thromb Vasc Biol 27: 454-460, 2007.

27. Rau JC, Deans C, Hoffman MR, Thomas DB, Malcom GT, Zieske AW, Strong JP, Koch GG and Church FC: Heparin cofactor II in atherosclerotic lesions from the Pathobiological Determinants of Atherosclerosis in Youth (PDAY) study. Exp Mol Pathol 87: 178-183, 2009.

28. Ikeda Y, Aihara K, Yoshida S, Iwase T, Tajima S, IzawaIshizawa Y, Kihira Y, Ishizawa K, Tomita S, Tsuchiya K, et al: Heparin cofactor II, a serine protease inhibitor, promotes angiogenesis via activation of the AMP-activated protein kinaseendothelial nitric-oxide synthase signaling pathway. J Biol Chem 287: 34256-34263, 2012.

29. Liao WY, Ho CC, Hou HH, Hsu TH, Tsai MF, Chen KY, Chen HY, Lee YC, Yu CJ, Lee CH, et al: Heparin co-factor II enhances cell motility and promotes metastasis in non-small cell lung cancer. J Pathol 235: 50-64, 2015.

30. Cavalcante MS, Torres-Romero JC, Lobo MD, Moreno FB, Bezerra LP, Lima DS, Matos JC, Moreira RA and MonteiroMoreira AC: A panel of glycoproteins as candidate biomarkers for early diagnosis and treatment evaluation of B-cell acute lymphoblastic leukemia. Biomark Res 4: 1, 2016.

31. Zhuang H, Gao J, Hu Z, Liu J, Liu D and Lin B: Co-expression of Lewis y antigen with human epididymis protein 4 in ovarian epithelial carcinoma. PLoS One 8: e68994, 2013.

32. Li J, Chen H, Mariani A, Chen D, Klatt E, Podratz K, Drapkin R, Broaddus R, Dowdy S and Jiang SW: HE4 (WFDC2) promotes tumor growth in endometrial cancer cell lines. Int J Mol Sci 14: 6026-6043, 2013.

33. Lu Q, Chen H, Senkowski C, Wang J, Wang X, Brower S, Glasgow W, Byck D, Jiang SW and Li J: Recombinant HE4 protein promotes proliferation of pancreatic and endometrial cancer cell lines. Oncol Rep 35: 163-170, 2016. 